\title{
AL-IQTISHADIYAH
}

Jurnal Ekonomi Syariah dan Hukum Ekonomi Syariah

E-ISSN: 2621-0274; P-ISSN: 2442-2282

Volume 6, Nomor 1, Juni 2020

\section{UPAYA PENINGKATAN PENDAPATAN NASIONAL DI TENGAH WABAH VIRUS CORONA PERSPEKTIF EKONOMI ISLAM}

\section{Eka Sri Apriliana}

Institut Agama Islam Negeri Palangkaraya, Indonesia. E-mail: ekasriaprilliana308@gmail.com

\begin{tabular}{|c|c|}
\hline ARTICLE INFO & ABSTRACT \\
\hline $\begin{array}{l}\text { Cara Sitasi: } \\
\text { Apriliana, Eka Sri. } \\
\text { “Upaya Peningkatan } \\
\text { Pendapatan Nasional di } \\
\text { Tengah Wabah Virus } \\
\text { Corona Perspektif } \\
\text { Ekonomi Islam." Al- } \\
\text { Iqtishadiyah: Jurnal } \\
\text { Ekonomi Syariah dan } \\
\text { Hukum Ekonomi } \\
\text { Syariah VI, no. } 1 \\
\text { (2020): 19-28. }\end{array}$ & $\begin{array}{l}\text { Tujuan dari penelitian ini untuk mengetahui upaya } \\
\text { peningkatan pendapatan nasional ditengah wabah virus } \\
\text { Corona perspektif ekonomi Islam. Pendekatan pada } \\
\text { penelitian ini menggunakan kualitatif dan jenis penelitiannya } \\
\text { yaitu studi dokumen dengan menganalisis upaya peningkatan } \\
\text { pendapatan nasional melalui beberapa kebijakan yang dibuat } \\
\text { pemerintah dan kebijakan yang dilihat dari ekonomi Islam } \\
\text { yang ada pada masa Rasulullah, Khulafaurasydin, dan masa } \\
\text { periode awal. Dari hasil analisis diperoleh bahwa upaya } \\
\text { peningkatan pendapatan nasional ditengah wabah virus } \\
\text { Corona perspektif ekonomi Islam dapat dilakukan melalui } 4 \\
\text { tolak ukur yaitu pendapatan individu rumah tangga, produksi } \\
\text { di sekto pedesaan kesejahteraan, adannya nilai santunan } \\
\text { antarsaudara dan zakat, infaq, serta sedekah. }\end{array}$ \\
\hline
\end{tabular}

\section{Pendahuluan}

Virus Corona adalah zoonotic yang artinya ditularkan antara hewan dan manusia. Berdasarkan data di Kementerian Kesehatan Indonesia, perkembangan kasus COVID19 di Wuhan dimulai pada tanggal 30 Desember 2019 di mana Komite Kesehatan Kota 
Wuhan mengeluarkan pernyataan "urgent notice on the treatment of pneumonia of unknown cause". penyebaran virus Corona bahkan sangat cepat untuk lintas negara. ${ }^{1}$ Dewasa ini terdapat 188 negara yang mengkorfirmasi terkena virus Corona. Penyebaran virus Corona membawa dampak pada perekonomian di Indonesia tidak hanya di Indonesia saja tetapi telah meluas ke berbagai belahan dunia manapun. baik dari sisi perdagangan, investasi dan pariwisata ${ }^{2}$ sehingga menimbulkan kekurangan pendapatan nasional negara karena terdampak adanya COVID-19.

Indonesia merupakan salah satu dari banyaknya negara yang terdampak COVID-19, dari berbagai hal yang terjadi seperti menurunnya ekspor migas dan non migas yang ditunjukkan oleh BPS bahwa nilai ekspor Indonesia pada bulan April 2020 mencapai US\$12,19 miliar mengalami penurunan sebesar 13,33 persen dibanding ekspor Maret 2020. Ekspor non migas pada bulan April 2020 mencapai US\$11,58 miliar mengalami penurunan sebesar 13,66 persen dibanding Maret 2020. ${ }^{3}$

Virus Corona juga sangat berdampak pada sektor pariwisata. Data kementerian Pariwisata menunjukkan bahwa Kunjungan wisman ke Indonesia melalui seluruh pintu masuk bulan Maret 2020 berjumlah 470.898 kunjungan, mengalami penurunan sebesar -64,11\% dibandingkan bulan Maret 2019 yang berjumlah 1.311 .911 kunjungan. ${ }^{4}$ Selain dari sektor ekspor dan sektor pariwisata dampak COVID-19 ini pun sangat dirasakan pada penurunan penerimaan pajak seperti yang dikatakan Menteri Keuangan Sri Mulyani memperkirakan bahwa Indonesia mengalami penurunan pendapatan negara sebesar $10 \%$ tahun ini. Penurunan pendapatan ini terutama akan terjadi pada sisi pendapatan pajak. ${ }^{5}$ Dari 3 kasus ekonomi tersebut menunjukkan bahwa kasus COVID-19 ini dapat mempegaruhi aspek ekonomi makro dari segi pendapatan nasional.

Penurunan pendapatan negara akibat terdampak COVID-19 mengakibatkan pemerintah harus berupaya meningkatkan kebijakan-kebijakan moneter maupun fiskal agar dapat menstabilkan pendapatan negara. Dalam ekonomi Islam penurunan pendapatan negara dijawab oleh beberapa kebijakan yang dilakukan pada masa Rasulullah dan Khulafaurasyidin maupun masa periode awal Islam. Sehingga peneliti merasa perlu adanya kajian yang lebih dalam mengenai penelitian ini dengan judul

\footnotetext{
1 "Kementerian Kesehatan Republik Indonesia," accessed May 18, 2020, https://www.kemkes.go.id/.

${ }^{2}$ Silpa Hanoatubun, "Dampak Covid - 19 Terhadap Prekonomian Indonesia," EduPsyCouns: Journal of Education, Psychology and Counseling 2, no. 1 (April 14, 2020): 146-53.

${ }^{3}$ Badan Pusat Statistik, “Ekspor April 2020 Mencapai US\$12,19 Miliar Dan Impor April 2020 Sebesar US\$12,54 Miliar," May 2020, https://www.bps.go.id/pressrelease/2020/05/15/1678/ekspor-april-2020-mencapai-us-12-19-miliardan-impor-april-2020-sebesar-us-12-54-miliar.html.

4 "Data Kunjungan Wisatawan Mancanegara Bulanan Tahun 2020," kemenpar.go.id, accessed May 18, 2020, http://www.kemenparekraf.go.id/post/data-kunjungan-wisatawan-mancanegara-bulanantahun-2020.

${ }^{5}$ Hendra Friana, "COVID-19 Tekan Perekonomian, Pendapatan Negara Diprediksi Turun 10\%," tirto.id, accessed May 18, 2020, https://tirto.id/covid-19-tekan-perekonomian-pendapatan-negara-diprediksiturun-10-eKdb.
} 
Upaya Peningkatan Pendapatan Nasional di Tengah Wabah Virus Corona Perspektif Ekonomi Islam.

Silpa Hanoatubun misalnya melakukan penelitian tentang dampak COVID-19 terhadap perekonomian Indonesia. la mengemukakan bahwa dampak COVID-19 dirasakan semua sektor ekonomi dan lapisan masyarakat seperti kesusahan dalam mencari lapangan pekerjaan,susah untuk memenuhi kebutuhan hidup sehari-hari dan juga tidak mempunyai penghasilan dalam memenuhi kebutuhan untuk sehari-hari. ${ }^{6}$

Yenti Sumarni melakukan penelitian yang berjudul Manajemen Ekonomi Islam dalam Menangani Pandemi Coronavirus Disease (COVID-19) di Indonesia. la mengemukakan bahwa ada 3 hal yang sesuai dengan manajemen ekonomi Islam pertama transaksi menggunakan Bank sentral, kedua mengenai upah nominal sudah terealisasi dengan baik sesuai dengan ekonomi syariah, ketiga mengenai kebijakan perokonomian telah memiliki tujuan-tujuan yang berkaitan terhadap ekonomi Islam. ${ }^{7}$

\section{Pendapatan Nasional}

Pendapatan nasional menurut Mukti Hakim adalah jumlah dari semua pendapatan yang diterima oleh orang-orang di suatu negara selama satu tahun. ${ }^{8}$ Dalam ilmu ekonomi konvensional, pendapatan nasional dapat dihitung dengan menggunakan jumlah GNP (Gross Nastional Produk). ${ }^{9}$ Dari pembelajaran teori ekonomi makro kita pahami untuk mengukur besarnya GNP berdasarkan dari 3 yakni pengeluaran untuk membeli barang dan jasa, nilai barang dan jasa akhir, dan faktor produksi dengan menjumlahkan penerimaan yang diterima oleh pemilik faktor produksi (upah, bunga, sewa, keuntungan). ${ }^{10}$

Penggunaan GNP dalam mengukur pendapatan nasional kurang mampu menggambarkan tingkat kemakmuran suatu bangsa. Ada beberapa hal yang membuat GNP kurang mampu digunakan untuk mengukur suatu bangsa yaitu hanya produk tertentu yang dapat memasuki pasar, GNP tidak dapat menghitung nilai sisa, kejadian buruk seperti bencana alam tidak dihitung dalam GNP, dan masalah polusi. ${ }^{11}$

\footnotetext{
${ }^{6}$ Hanoatubun, “Dampak Covid - 19 Terhadap Prekonomian Indonesia."

${ }^{7}$ Yenti Sumarni, “Manajemen Ekonomi Islam dalam Menangani Pandemi Coronavirus Disease (COVID19) di Indonesia," Jurnal BAABU AL-ILMI: Ekonomi dan Perbankan Syariah 5, no. 1 (April 30, 2020): 11726, https://doi.org/10.29300/ba.v5i1.3123.

${ }^{8}$ Mukti Hakim, Pendapatan Nasional (Jakarta: Badan Pusat Statistik Nasional.[Penerjemah]. Jakarta, 2015).

${ }^{9}$ Mustafa Edwin Nasution, Ekonomi Islam (Jakarta: Kencana, 2007), 193.

10 Muhammad Kholis, Diah Astuti, and Rini Febrianti, “Hubungan Antara Pendapatan Nasional Dan Investasi Di Indonesia (Suatu Kajian Ekonomi Makro Dengan Model VAR)," Jurnal Organisasi Dan Manajemen 12, no. 1 (March 27, 2016): 65-78, https://doi.org/10.33830/jom.v12i1.48.2016.

${ }^{11}$ Mustafa Edwin Nasution, Ekonomi Islam, 194.
} 
Berbeda dengan Ekonomi Islam pendapatan nasional yang diterapkan melalui GNP lebih menekankan kepada falah. Falah merupakan kesejahteraan yang hakiki, di mana komponen spiritual masuk ke dalam falah tersebut. ${ }^{12}$ Dalam ekonomi Islam peningkatan GNP diwujudkan pada kesejahteraan masyarakat dalam rangka agar mencapai Falah, karena itu semua aspek dari kegiatan duniawi termasuk aspek ekonomi diarahkan tidak hanya untuk memenuhi tuntutan fisik tetapi juga memenuhi kebutuhn spiritual. ${ }^{13}$

Konsep ekonomi kapitalis yang mengukur tingkat pendapatan nasional untuk GNP jelas akan mengabaikan kegiatan spiritual umat manusia. Pola dan proses pembangunan ekonomi diarahkan semata-mata untuk pendapatan perkapital, hal ini akan mengarahkan manusia ke konsumsi fisik yang cenderung hedonis. ${ }^{14}$ Maka dari itu, ekonomi Islam yang sudah di atur dalam Alquran dan Assunah memasukkan unsur falah dalam upaya peningkatan pendapatan nasional melalui beberapa kebijakan yang pernah diterapkan pada masa Rasulullah dan Khulafaurasyidin serta pada awal periode Islam seperti menerapkan instrument zakat, wakaf, dan sedekah dari hal inilah yang diperlukan untuk mencapai kesejahteraan masyarakat.

\section{Metode Penelitian}

\section{Pendekatan dan Jenis Penelitian}

Metode adalah suatu cara atau jalan. Maka metode penelitian adalah cara atau jalan yang digunakan dalam penelitian. ${ }^{15}$ Pendekatan pada penelitian ini menggunakan kualitatif. Pendekatan kualitatif adalah studi penelitian deskriptif dan cenderung menggunakan analisis. Penelitian ini bertujuan untuk menganalisis secermat mungkin sesuatu yang menjadi obyek, fenomena atau kelompok. Penelitian ini menelaah tentang upaya peningkatan pendapatan nasional di tengah wabah COVID-19 dilihat pada kacamata ekonomi Islam.

Jenis penelitian ini merupakan penelitian studi dokumen (Document Study), yaitu kajian yang menitik beratkan pada analisis. ${ }^{16}$ Sehingga pada penelitian ini menggunakan analisis pada upaya untuk peningkatkan pendapatan nasional.

\section{Data dan Sumber Data}

Fokus penelitian ini lebih pada analisis upaya peningkatan pendapatan nasional di tengah wabah COVID-19. Oleh karena itu sumber data yang digunakan dalam

12 Vinna Sri Yuniarti;, Ekonomi Makro Syariah (Pustaka Setia, 2016), //senayan.iainpalangkaraya.ac.id/index.php?p=show_detail\&id=12021\&keywords=.

${ }^{13}$ Mustafa Edwin Nasution, Ekonomi Islam, 195.

${ }^{14}$ Mustafa Edwin Nasution, 197.

${ }^{15}$ Hasan, Fuad dan Koentjaraningrat, Beberapa Asas Metodologi Ilmiah (Jakarta: Gremedia, 1994), 7.

${ }^{16}$ Mudjia Rahardjo, "Jenis Dan Metode Penelitian Kualitatif," Tersedia Secara Online Di: Http://Mudjiarahardjo. Com/Materi-Kuliah/215-Jenis-Dan-Metode-Penelitian-Kualitatif. Html [Diakses Di Jakarta, Indonesia: 15 Juni 2015], 2010. 
penelitian ini adalah sumber data sekunder. Sumber Data Sekunder: merupakan sumber yang dapat memberikan informasi atau data tambahan yang dapat memperkuat data dasar, baik dalam bentuk manusia atau benda ${ }^{17}$ seperti: literatur perpustakaan, media cetak dan elektronik yang berkaitan dengan permasalahan yang dibahas.

\section{Analisis Data}

Berdasarkan data yang telah terkumpul yaitu data sekunder, peneliti melakukan analisis data dengan menggunakan metode analisis secara induktif adalah analisis yang dilakukan berdasarkan teori-teori yang dikumpulkan dengan sistematika dari bawah ke atas. ${ }^{18}$ Pola pikir induktif adalah metode yang digunakan untuk menganalisis upaya peningkatan pendapatan di tengah wabah COVID-19 yang di lihat dari ekonomi Islam.

\section{Temuan dan Analisis}

Peningkatan virus pada negara yang terkena dampak COVID-19 di dunia seperti Amerika, Spanyol dan Italia membuat situasi ekonomi dunia semakin buruk. Beberapa lembaga bahkan memprediksi melemahnya ekonomi dunia, termasuk International Monetary Fund (IMF) memproyeksikan bahwa ekonomi global tumbuh pada tingkat minus $3 \% .{ }^{19}$

Belakangan ini COVID-19 menjadi konsen besar bangsa Indonesia karena permasalahan yang terus ditimbulkannya, ada banyak kerugian yang disebabkan oleh COVID-19 yang berdampak bagi perekonomian Indonesia salah satunya kerugian pada pendapatan nasional negara. ${ }^{20}$ Adanya wabah virus ini mengakibatkan pendapatan nasional mengalami penurunan.

Pendapatan nasional Negara diperoleh dari beberapa sektor salah satunya penerimaan pajak yang setiap bulannya mengalami penurunan. Seperti pada tabel di bawah ini perbedaan pendapatan Negara dengan adanya COVID-19

\footnotetext{
${ }^{17}$ Bambang Irawan, "Penerapan Akad Rahn Dan Penentuan Biaya Ijarah Dalam Sistem Gadai Syariah Menurut Fatwa DSN-MUI No 25/III/2002 (Studi Kasus Di PT. Pegadaian (Persero) CPS Cabang Blauran)," MAQASID 2, no. 2 (2018).

${ }^{18}$ Kasiram, Metodologi Penelitian Kualitatif-Kuantitatif (Yogyakarta: Sukses Ofset, 2010), 175-76.

19 Kementerian Keuangan Republik Indonesia, “Pemerintah Waspada Dampak Pandemi Covid-19 Terhadap Ekonomi Indonesia," Siaran Pers, April 17, 2020.

${ }^{20}$ Hanoatubun, "Dampak Covid - 19 Terhadap Prekonomian Indonesia."
} 
Tabel 1. Realisasi Penerimaan Pajak ${ }^{21}$

(dalam triliun rupiah)

\begin{tabular}{lccc}
\hline \multicolumn{1}{c}{ Uraian } & APBN 2020 & \multicolumn{2}{c}{ Realisasi Januari -Maret } \\
& & \multicolumn{2}{c}{$2019-2020$} \\
\hline Pajak Penghasilan & 929,90 & 147,81 & $-5,40$ \\
\hline Non Migas & 872,48 & 137,47 & $-3,04$ \\
\hline Migas & 57,43 & 10,34 & $-28,57$ \\
\hline PPN \& PPnBM & 685,87 & 91,97 & 2,47 \\
\hline PBB (Sektor P3) & 18,86 & 1,83 & 6,70 \\
\hline Jumlah & $1.642,57$ & 241,61 & $-2,47$ \\
\hline
\end{tabular}

Sumber: Kementerian Keuangan “APBN Kita Kinerja Dan Fakta”

Tabel diatas menunjukkan bahwa dalam penerimaan pajak di Indonesia mengalami penurunan yang sangat signifikan hal ini disebabkan beberapa faktor salah satu faktor yang mendukung yaitu adanya COVID-19 yang membuat lemahnya pendapatan nasioanl.

Berdasarkan pemantauan dari perkembangan Menteri Keuangan dalam pembayaran wajib pajak hingga akhir kuartal pertama mengalami perlambatan ekonomi dan efek dari pandemi COVID-19, sejauh ini masih lebih mempengaruhi kinerja penerimaan pajak dari sisi supply (penawaran), terutama di sektor-sektor yang memiliki hubungan erat (linkage) dengan rantai produksi global dan perdagangan internasional, khususnya kegiatan ekspor-impor. Sementara itu, dari sisi demand (permintaan), kinerja penerimaan pajak belum menunjukkan dampak langsung dari pandemi COVID19 , terutama konsumsi domestik. ${ }^{22}$

Tekait hal tersebut pemerintah berupaya meningkatkan pendapatan nasional dari sektor perpajakan yang menjadi salah satu sumber pendapatan nasional. Akhir maret pemerinth telah mengeluarkan 3 kebijakan strategis dibidang perpajakan yaitu:

1. Peraturan Menteri Keuangan Nomor 23 / PMK.03 / 2020 tentang Insentif Pajak bagi Wajib Pajak Terdampak Virus Wabah Corona, insentif yang diberikan kepada wajib pajak di sektor-sektor tertentu dalam bentuk 6 bulan untuk pekerja dengan pendapatan kotor tidak lebih dari 200 juta yang tidak ditanggung oleh pemerintah, pembebasan pajak impor selama 6 bulan, Pengurangan pajak Pasal 25 sebesar 30

\footnotetext{
${ }^{21}$ Menteri Keuangan dan Wakil Menteri Keuangan, APBN Kita Kinerja Dan Fakta (Jakarta: Kementerian Keuangan Republik Indonesia, 2020), 35.

${ }^{22}$ Friana, "COVID-19 Tekan Perekonomian, Pendapatan Negara Diprediksi Turun 10\%."
} 
persen selama 6 bulan, restitusi PPN dipercepat selama 6 bulan bagi eksportir serta hingga Rp 5 miliar untuk non-eksportir.. ${ }^{23}$

2. PERPPU No 1 tahun 2020 tentang Kebijakan Keuangan Negara dan Stabilitas Sistem Keuangan untuk Penanganan pandemi Corona Virus Disease 2019 (COVID-19) dan/atau dalam rangka Menghadapi Ancaman yang membahayakan Perekonomian Nasional dan/atau Stabilitas. Terdapat beberapa kebijakan strategis perpajakan yang diatur dalam PERPPU tersebut penurunan tarif PPh Badan secara bertahap dari 25\% menjadi 22\% untuk tahun pajak 2020 dan 2021, sedangkan untuk perusahaan go public tarif tersebut masih dikurangi lagi sebesar $3 \%$, menjadi $19 \%$ dan $17 \%$, perpanjangan permohonan/penyelesaian administrasi perpajakan, memberikan level playing field dan dengan mengingat keterbatasan transaksi konvensional melalui tatap muka di masa social distancing. ${ }^{24}$

3. Peraturan Menteri Keuangan Nomor 28/PMK.03/2020 tentang Pemberian Fasilitas Pajak Barang dan Jasa yang dibutuhkan di masa Penanganan Pandemi Corona Virus Disease 2019 dengan mendukung ketersediaan obat-obatan, peralatan medis, dan alat-alat pendukung lainnya dalam penanganan pandemi COVID-19. ${ }^{25}$

Kebijakan di atas diterapakan pemerintah untuk upaya meningkatkan pendapatan nasional agar dapat meminimalisir dampak COVID-19. Selain kebijakan pemerintah yang telah menyusun strategi untuk meningkatkan pendapatan nasional, Ekonomi Islam pun hadir dalam mengatur langkah dan strategi kebijakan guna meningkatkan pendapatan nasional yang sesuai dengan Alquran dan Hadis di tengah wabah virus ini.

Ada 4 hal yang dapat diukur untuk meningkatkan pendapatan nasional perspektif ekonomi Islam, yaitu: ${ }^{26}$

1. Mengetahui penyebaran pendapatan individu rumah tangga. perhitungan pendapatan nasional Islam harus mampu mengenali penyebaran alamiah dari output perkapital, karena jika memahami pendapatan individu secara nasional bisa dideteksi dengan akurat, Negara akan mudah untuk mengetahui berapa banyak masyarakat yang masih hidup di bawah garis kemiskinan. Hal ini sama dengan kasus COVID-19 yang dimana ketika pemerintah melakukan kebijakan untuk pembagian BLT (bantuan langsung tunai) bagi masyarakat yang tedampak COVID-19 maka pemerintah harus mengetahui penyebaran pendapatan individu baik berupa produksi maupun konsumsi yang dihasilkan atau digunakan individu agar pembagian merata dan adil.

2. Mengetahui produksi di sektor pedesaan. Untuk mengetahui perkiraan produksi komunitas ini harus diketahui terlebih dahulu tingkat harga yang digunakan. Secara umum ada dua jenis harga pasar yaitu harga yang diterima petani dan harga yang

\footnotetext{
${ }^{23}$ Menteri Keuangan dan Wakil Menteri Keuangan, APBN Kita Kinerja Dan Fakta, 41.

${ }^{24}$ Kementerian Keuangan Republik Indonesia, "Pemerintah Waspada Dampak Pandemi Covid-19 Terhadap Ekonomi Indonesia," 4.

${ }^{25}$ Menteri Keuangan dan Wakil Menteri Keuangan, APBN Kita Kinerja Dan Fakta, 41.

${ }^{26}$ Mustafa Edwin Nasution, Ekonomi Islam, 197-201.
} 
dibayar oleh konsumen di pasar ritel. Ketidakmampuan mendeteksi secara akurat pendapatan dari sektor pedesaan jelas merupakan kelemahan yang harus diatasi, karena di sektor ini masyarakat bergantung hidup dalam jumlah besar, dan ini adalah inti dari masalah ketimpangan dalam tidak meratanya distribusi pendapatan. Dalam situasi saat ini yang sedang melanda Indonesia akibat sebuah virus yang bernama corona mengakibtakan tidak meratanya distribusi pendapatan yang dirasa oleh masyarakat menengah kebawah dan masyarakat yang merasakan dampak dari adanya COVID-19.

3. Mengetahui ukuran kesejahteraan ekonomi Islam. Mengukur kesejahteraan ekonomi Islam dapat ditemukan dari kemampuan Negara untuk menyediakan kebutuhan dasar seperti makanan, perumahan, kesehatan, pendidikan, air bersih, rekreasi dan pelayanan publik lainnya.. Sehingga untuk melihat keadaan kita masyarakat Indonesia yang sekarang ini sedang berjuang mengatasi COVID-19 maka diperlukan adanya peran pemerintah dalam menyedikan kebutuhan dasar bagi masyarakat mengalami dampak dari adanya virus tersebut.

4. Mengetahui nilai santunan antar saudara dan zakat, infaq sedekah. Zakat, dan sedekah infaq memiliki peran yang signifikan dalam masyarakat Muslim, dan ini merupakan bagian dari kepatuhan dalam menjalankan kehidupan beragama.. Dalam ekonomi Islam terdapat tanggungjawab untuk menyantuni saudara atau kerabat yang sedang mengalami masalah ekonomi. Dengan adanya zakat dan sedekah dapat menjadi pengukur pendapatan nasional yang dipersentasikan dalam GNP. Ditengah adanya COVID-19 masyarakat yang terdampak memerlukan bantuan kepada masyarakat yang tidak terdampak dengan memberikan sedikit harta yang dimiliki seperti zakat, infaq dan sedekah, karena dengan pemberian tersebut dapat menaikkan pendapatan nasional.

Dari tolak ukur diatas maka upaya meningkatkan pendapatan nasional dapat dilakukan dengan berbagai cara. Dalam ekonomi Islam cara tersebut dapat berupa pengelolaan pendapatan Negara. Pada masa Rasulullah, Khulafaurasyidin, dan awal periode Islam pendapatan Negara melalui beberapa sektor yaitu Zakat, Usyr, Khumus, Ghanimah, Fai, Kharaj, Jizyah, sedekah, infaq, dan wakaf sedangkan dari sektor keuangan pada masa tersebut tidak pernah mengalami penurunan pendapatan karena menggunakan dinar dan dirham yang tidak mengalami inflasi terhadap mata uang itu sendiri.

Kita bangsa Indonesia yang masyarakatnya mayoritas muslim dapat menjadikan masa Rasulullah, Khulafaurasyidin, dan awal periode Islam sebagai teladan dalam mengatasi wabah COVID-19 dengan mencontoh sejumlah kebijakan untuk meningkatkan pendapatan negara. Indonesia adalah salah satu dari banyak negara yang mengalami penurunan pendapatan di tengah COVID-1927, solusi untuk mengatasi hal ini kita dapat

27 Azwar, "Solusi Ekonomi Dan Keuangan Islam Saat Pandemi COVID-19," April 5, 2020, https://www.kemenkeu.go.id/publikasi/artikel-dan-opini/solusi-ekonomi-dan-keuangan-islam-saatpandemi-covid-19/. 
berkaca dari kebijakan ekonomi Islam pada waktu itu. Salah satu kebijakan tersebut yang sesuai dengan keadaan kita saat ini yaitu:

1. Menerapkan pembayaran melalui zakat seperti zakat maal dan zakat fitrah yang nantinya pembayaran zakat tersebut disalurkan bagi masyarakat yang terdampak COVID-19 sehingga permintaan akan produksi mengalami peningkatan dan akhirnya kembali kepada negara.

2. Menguatkan wakaf uang baik dengan skema wakaf tunai, wakaf produktif maupun waqaf linked sukuk yang perlu ditingkatkan. Badan wakaf Indonesia (BWI) perlu berkerja sama dengan lembaga keuangan syariah untuk mempromosikan berbagai infastruktur berbasis wakaf yang dimana pembangunan tersebut dapat meningkatkan pendapatan nasional.

\section{Penutup}

Berdasarkan penjelasan diatas, upaya peningkatan pendapatan ditengah wabah COVID-19 ini meliputi dari 2 aspek. Aspek pertama upaya yang dilakukan pemerintah dalam peningkatan pendapatan nasional berupa kebijakan fiskal yaitu kebijakan yang di keluarkan oleh pemerintah yang mengacu kepada ketentuan dalam perpajakan. Aspek yang kedua berupa upaya peningkatan pendapatan nasional dilihat dari segi ekonomi Islam yang dimana dalam peningkatan pendapatan ada 4 tolak ukur yang menjadi acuan sehingga hadirlah kebijakan seperti pada masa Rasulullah, Khulafaurasyidin, dan awal periode Islam dengan mengedepankan sektor wakaf dan zakat yang dapat kita terapkan untuk upaya peninngkatan pendapatan nasional suatu Negara yang terdampak COVID-19.

Maka disarankan kepada pemerintah agar terus berupaya dalam menningkatkan pendapatan nasional dengan menerapkan beberapa system atau kebijakan seperti pada masa Rasulullah, Khulafaurasyidin, dan awal periode Islam untuk menghadapi wabah COVID-19.

\section{DAFTAR PUSTAKA}

Azwar. "Solusi Ekonomi Dan Keuangan Islam Saat Pandemi COVID-19," April 5, 2020. https://www.kemenkeu.go.id/publikasi/artikel-dan-opini/solusi-ekonomidan-keuangan-islam-saat-pandemi-covid-19/.

Badan Pusat Statistik. “Ekspor April 2020 Mencapai US\$12,19 Miliar Dan Impor April 2020 Sebesar US\$12,54 Miliar." Accessed May 18, 2020. https://www.bps.go.id/pressrelease/2020/05/15/1678/ekspor-april-2020mencapai-us-12-19-miliar-dan-impor-april-2020-sebesar-us-12-54miliar.html.

kemenpar.go.id. "Data Kunjungan Wisatawan Mancanegara Bulanan Tahun 2020." Accessed May 18, 2020. http://www.kemenparekraf.go.id/post/datakunjungan-wisatawan-mancanegara-bulanan-tahun-2020. 
Friana, Hendra. "COVID-19 Tekan Perekonomian, Pendapatan Negara Diprediksi Turun 10\%." tirto.id. Accessed May 18, 2020. https://tirto.id/covid-19-tekanperekonomian-pendapatan-negara-diprediksi-turun-10-eKdb.

Hakim, Mukti. Pendapatan Nasional. Jakarta: Badan Pusat Statistik Nasional.[Penerjemah]. Jakarta, 2015.

Hanoatubun, Silpa. "Dampak Covid - 19 Terhadap Prekonomian Indonesia." EduPsyCouns: Journal of Education, Psychology and Counseling 2, no. 1 (April 14, 2020): 146-53.

Hasan, Fuad dan Koentjaraningrat. Beberapa Asas Metodologi Ilmiah. Jakarta: Gremedia, 1994.

Irawan, Bambang. "Penerapan Akad Rahn Dan Penentuan Biaya ljarah Dalam Sistem Gadai Syariah Menurut Fatwa DSN-MUI No 25/III/2002 (Studi Kasus Di PT. Pegadaian (Persero) CPS Cabang Blauran)." MAQASID 2, no. 2 (2018).

Kasiram. Metodologi Penelitian Kualitatif-Kuantitatif. Yogyakarta: Sukses Ofset, 2010.

“Kementerian Kesehatan Republik Indonesia." Accessed May 18, 2020. https://www.kemkes.go.id/.

Kementerian Keuangan Republik Indonesia. "Pemerintah Waspada Dampak Pandemi Covid-19 Terhadap Ekonomi Indonesia." Siaran Pers. April 17, 2020.

Kholis, Muhammad, Diah Astuti, and Rini Febrianti. "Hubungan Antara Pendapatan Nasional Dan Investasi Di Indonesia (Suatu Kajian Ekonomi Makro Dengan Model VAR)." Jurnal Organisasi Dan Manajemen 12, no. 1 (March 27, 2016): 65-78. https://doi.org/10.33830/jom.v12i1.48.2016.

Menteri Keuangan dan Wakil Menteri Keuangan. APBN Kita Kinerja Dan Fakta. Jakarta: Kementerian Keuangan Republik Indonesia, 2020.

Mustafa Edwin Nasution. Ekonomi Islam. Jakarta: Kencana, 2007.

Rahardjo, Mudjia. "Jenis Dan Metode Penelitian Kualitatif." Tersedia Secara Online Di: Http://Mudjiarahardjo. Com/Materi-Kuliah/215-Jenis-Dan-MetodePenelitian-Kualitatif. Html [Diakses Di Jakarta, Indonesia: 15 Juni 2015], 2010.

Sumarni, Yenti. "Manajemen Ekonomi Islam dalam Menangani Pandemi Coronavirus Disease (COVID-19) di Indonesia." Jurnal BAABU AL-ILMI: Ekonomi dan Perbankan Syariah 5, no. 1 (April 30, 2020): 117-26. https://doi.org/10.29300/ba.v5i1.3123.

Yuniarti;, Vinna Sri. Ekonomi Makro Syariah. Pustaka Setia, 2016. //senayan.iainpalangkaraya.ac.id/index.php?p=show_detail\&id=12021\&keywords=. 